\title{
Safety assessment of silica and zinc oxide nanoparticles
}

\author{
This article was published in the following Dove Press journal: \\ International Journal of Nanomedicine \\ 15 December 2014 \\ Number of times this article has been viewed
}

\section{Seong Soo A An' \\ Meyoung-Kon Kim²}

'Department of Bionanotechnology, Gachon Medical Research Institute, Gachon University, Seongnam, Gyeonggi, Korea; ' $D$ Department of Biochemistry and Molecular Biology, Korea University Medical School and College, Seoul, Korea
Correspondence: Meyoung-Kon Kim Department of Biochemistry and Molecular Biology, Korea University Medical School and College,

Anam-Dong $5 \mathrm{Ga}$, Seoungbuk-Gu, Seoul I35-70I, Korea

$\mathrm{Tel}+8229206184$

Fax +82 29230480

Email jerrykim@korea.ac.kr
The current volume is a special issue focusing on a safety assessment of nanoparticles, from their physicochemical properties to government regulations. It features twenty-five papers, discussing general issues with the possible harmfulness of two different types of nanoparticles (NPs); silica $\left(\mathrm{SiO}_{2}\right)$ and zinc oxide $(\mathrm{ZnO})$. Six papers describe detailed analyses from 90-day repeated administrations of NPs, and finally there is a series of technical reports, formatted by the National Toxicology Program (NTP), dealing with safety issues regarding international cooperation with the OECD (Organisation for Economic Co-operation and Development) Working Party on Manufactured Nanomaterials (WPMN).

This initiative was created from fundamental and detailed investigations into $\mathrm{SiO}_{2}$ and ZnO NPs and their toxicological effects. In the spring of 2010, the Ministry of Food and Drug Safety (MFDS) (formerly the Korean Food and Drug Administration) selected the Research Team for Nano-Associated Safety Assessment (RT-NASA) to carry out a safety assessment on two nanomaterials, $\mathrm{ZnO}$ and $\mathrm{SiO}_{2}$, in which RT-NASA would confront both the Korean and international views on risk analysis and explore potential contributions toward, and global cooperation with, OECD WPMN. Eventually, separate NTP reports were prepared, presented, and discussed in June of 2013 at the MFDS, along with the primary research outcomes. These toxicity reports, along with our other collaborative efforts, are published in the present volume.

The discussions at the overview highlighted the detailed results from a wide spectrum of multidisciplinary fields by respective specialists, for example, physicochemists, toxicologists, biochemists, communication survey experts, veterinary researchers, and medical doctors. The core final analyses were weaved together and expanded upon. Through monthly and quarterly meetings, along with biyearly and yearly peer-reviews and international presentations at OECD WPMN, higher levels of cooperation were reached. Was there a rationale for an integrative approach in the safety assessment? Did we need a central control tower of research management and sample banking system in order to orchestrate the entire team? Should government play any role in the direction of research process, leading to establishing public regulations? At this point, addressing and publishing the issue of safety or toxicity came into the picture as the first priority for the present study, like seeing the whole forest instead of one individual tree. The controversy against nanomaterials, concerning both the potential exaggeration of their success and the threat of fear, was indeed an important accepted rationale for working in RT-NASA. The conviction that nanomaterials should be used within the safety range 
of governmental guidelines was the fundamental basis, which was shared by virtually all investigators, apart from those who viewed nanomaterials as either extreme, beneficial or harmful. This raised the question of whether we are now confronted with mere scientific limitations that have no supporting evidence in the system of safety assessment, or with a strategic necessity for further investigation into target organs and tolerable concentrations for administrating nanomaterials.

Safety assessment is not only a tool to be used in deciding large or future governmental regulations, but also a way to shed light on scientific curiosities, which provided us with the opportunity to discuss with and advise many industries on nanosafety and nanotoxicity. The efforts assembled in the present volume may contribute to such provisions. In particular, we hope that the current reports may be able to stimulate further investigations in the future, along with the other nanomaterials in their respective fields.

\section{Disclosure}

The authors report no conflicts of interest in this work.

\section{Publish your work in this journal}

The International Journal of Nanomedicine is an international, peerreviewed journal focusing on the application of nanotechnology in diagnostics, therapeutics, and drug delivery systems throughout the biomedical field. This journal is indexed on PubMed Central, MedLine, CAS, SciSearch $\AA$, Current Contents ${ }^{\circledR} /$ Clinical Medicine,
Journal Citation Reports/Science Edition, EMBase, Scopus and the Elsevier Bibliographic databases. The manuscript management system is completely online and includes a very quick and fair peer-review system, which is all easy to use. Visit http://www.dovepress.com/ testimonials.php to read real quotes from published authors. 